\title{
Epidemiology of Tomato Yellow Leaf Curl Virus in the Northern Regions of the West Bank, Palestine
}

\author{
Hazem Sawalha*
}

Department of Biology and Biotechnology, Faculty of Arts and Sciences Arab American University of Jenin - Palestine P. O. Box 240, USA

\begin{abstract}
A survey was carried out in 2011 to study the epidemiology of tomato yellow leaf curl virus (TYLCV) in tomato growing sites of the Tobas and the Jenin districts. The survey studied the population of the virus-inoculative whiteflies and the possible virus reservoirs throughout the year. The maximum TYLCV-inoculative whitefly population was recorded in Tobas, compared with the Jenin district in the different growing seasons of tomato. In the Tobas district, the inoculative whiteflies started to appear in March and reached the maximum value of $7 \%$ in July and August. In the Jenin district, the maximum inoculative whitefly population of $6 \%$ was recorded in August. Such whiteflies started to appear in May, which is two months after their appearance in the Tobas district. Furthermore, populations of inoculative whiteflies occurred when farmers started their tomato growing seasons. The appearance of inoculative whiteflies coincided with availability of the virus natural reservoirs which harbor the virus and support the vector during the crop-free period. Infected cheese weed mallows (up to 12\%) and tobacco plants (up to 7\%) were the virus sources for whiteflies throughout the year in the Tobas and the Jenin districts respectively. Infected volunteer tomatoes (up to 93\%) play a secondary role in the virus epidemiology as they disappear during winter (crop-free period) in both districts.
\end{abstract}

Keywords: TYLCV, Inoculative whiteflies, Epidemiology, Palestine.

\section{INTRODUCTION}

Tomato (Lycopersicon esculentum) is the most popular vegetable crop in Palestine. Its annual production is 204,000 metric tons which comprises about $32 \%$ of the total vegetable production in the country [1]. The crop is an important part of a diverse and balanced diet and provides colorful additions to any meal [2]. Also, Palestinian people use tomato fruit in their folkloric medicine [3].

Tomato yellow leaf curl virus (TYLCV) is the most devastating disease infecting tomato in many tropical and subtropical regions causing yield loss up to $100 \%$ [4-6]. Currently, in Palestine the virus is widely infecting tomatoes in northern regions of the West Bank including the Jenin and the Tobas districts. The highest rate of infection approaches $95 \%$ in the Tobas district during the summer growing season [7].

The virus has a quite broad host range, infecting plants belonging to solanaceae e.g. tobacco; malvaceae e.g. weed mallows; and lequiminosae e.g. beans [8,9]. The virus, much like other Gemini viruses, is not seed-transmissible [10]. The causal agent of the disease has been isolated and identified as a single-strand DNA containing geminivirus species of the genus Begomovirus, and most of which posses a monopartite genome $[11,12]$.

*Address correspondence to this author at the Department of Biology and Biotechnology, Faculty of Arts and Sciences Arab American University of Jenin - Palestine P. O. Box 240; Tel: 0097242510801; Fax: 0097242510810; E-mails: hsawalha@aauj.edu, hhh_sawalha@yahoo.com
The tropical whitefly Bemisia tabaci (Gennadius) (Hemiptera: Aleyrodidae) is the known vector for TYLCV [13, 14]. The insect is the most noxious pest attacking field and greenhouse crops including tomato around the world [15].

Tomato production in Palestine does not reach its full potential due to the high rate of TYLCV infection which is the key factor responsible for continuous crop failure [1, 7 , 16]. Whitefly population was reported to have two remarkable peaks in the northern regions of West Bank without paying any attention on the percentage of the inoculative whiteflies in the region [7]. Therefore, this research has studied the virus epidemiology in the northern regions of the west bank. Also, the research has studied the inoculative whiteflies and natural plant reservoirs which support the whiteflies before and during growing seasons. The northern regions were selected for this study as they are the major tomato growing sites in the country. The annual tomato production in these regions comprises $47 \%$ of the total tomato production in the West Bank [1].

\section{MATERIALS AND METHODS}

\section{Regions of Study}

Three regions were selected in the Jenin and the districts since they are the major contributors to tomato production in Palestine. The fields were selected in Al-Zababdeih and Qabatya regions to represent the Jenin district, whereas the fields of Al-Far'a region were selected to represent the Tobas district (Fig. 1). 


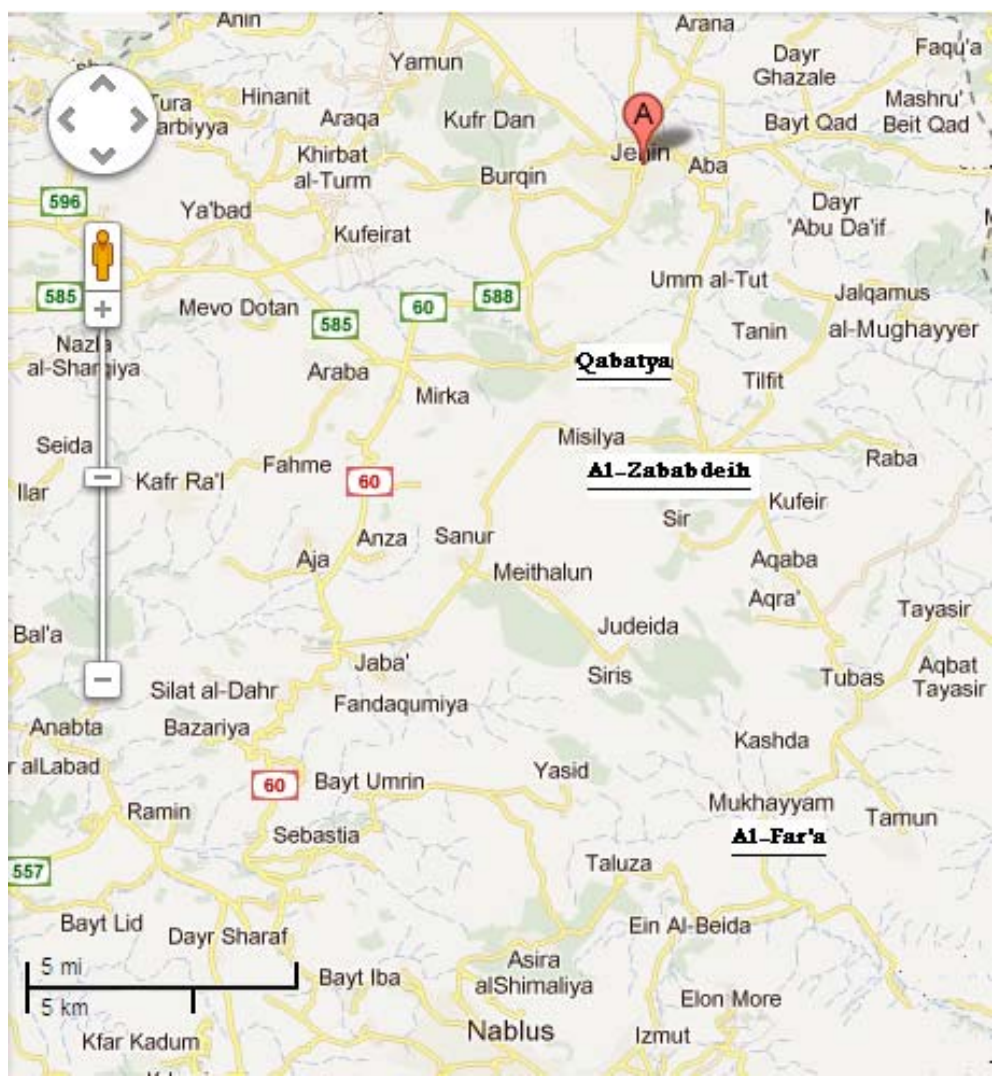

Fig. (1). A map of the Jenin and the Tobas districts showing the studied regions.

In addition the selected regions have the following weather conditions as reported by the Palestinian Meteorological General Directorate in 2011 (Table 1) [17].

\section{Growing Seasons}

Tomato is planted in the studied regions in different growing seasons including spring (March to April), summer (May to June) and autumn (July until September). The summer growing season is perhaps the most important as farmers usually cultivate tomato in larger areas. On the other hand, parts of the tomato-growing sites in the Jenin district are used during the summer season for tobacco cultivation which may increase the possibility for some residual tobacco plants to contaminate the soil as volunteers that harbour the virus in these sites.

\section{Occurrence of TYLCV in Plant Reservoirs}

The selected fields were visited monthly for sample collection starting from January until December 2011. Leaf

Table 1. Meteorological Conditions of the Studied Regions in 2011

\begin{tabular}{|c|c|}
\hline Weather Attribute & Mean Value \\
\hline \hline Air temperature & 21.8 Degree Celsius \\
\hline Rainfall & 336.5 Millimetre \\
\hline Relative humidity & $64 \%$ \\
\hline Evaporation & $2,102.7$ Millimetre \\
\hline Wind speed & $6.6 \mathrm{~km} / \mathrm{hour}$ \\
\hline
\end{tabular}

samples of volunteer tomato, tobacco and cheese weed mallow (Malva parviflora), the common weeds of tomato sites, were randomly collected from the top part of plants growing in approximately ten hectares of the studied area. Fifteen samples were collected from each plant type in every visit and prepared for polymerase chain reaction (PCR). Tobacco samples were collected only from the Jenin district because this plant was not found in any of the selected locations in the Tobas district.

\section{DNA Extraction}

The method of DNA extraction was done according to [18]. The leaf samples were crushed in liquid nitrogen and extracted in $50 \mathrm{ml}$ extraction buffer $(200 \mathrm{mM}$ tris- $\mathrm{HCl} \mathrm{pH}$ $8.5,250 \mathrm{mM} \mathrm{NaCl}, 25 \mathrm{mM}$ EDTA, $0.5 \%$ SDS) then sodium acetate $(3 \mathrm{M})(\mathrm{pH} 5.2)$ was added. After 5 min centrifugation, the supernatant was treated with chloroform-isoamylalcohol $(24: 1, \mathrm{v} / \mathrm{v})$, then precipitated by isopropanol. After centrifugation at $13,000 \mathrm{rpm}$, the pellet was washed with $70 \%$ ethanol, dried and resuspended in $12 \mathrm{ml}$ of TE buffer $(10 \mathrm{mM}$ Tris-HCl, 1 mM EDTA pH 8.0).

\section{PCR Testing}

The PCR was employed as described by Navot et al. (1992) using TYLCV-specific oligonucleotide primers [19]. Sub-genomic fragments of the virus genome were amplified. The primers were purchased from the Alltech Company, Paisley, UK. The primer sequences were from 5' to 3', P1V, ATACTTGGACACCTAATGGC, nucleotides (nt) 61-80, and P4C, TGGACATCTAGACCTAAG, nt. 2054-2071. The sequence of the $\mathrm{P} 1 \mathrm{~V}$ corresponds to the viron positive strand, whereas the $\mathrm{P} 4 \mathrm{C}$ is complementary to the viron strand. 



Fig. (2). Agar gel electrophoreses of amplified PCR products of TYLCV DNA from infected plants and inoculative whiteflies using $\mathrm{P} 1 \mathrm{~V}$ and $\mathrm{P} 4 \mathrm{C}$ primers.

Lane A: Inoculative whitefly

Lane B: DNA size marker (Lambda Hind III Eco R1, 123-21226 bp).

Lane C: Infected tobacco sample

Lane D: Infected tomato sample

Lane E: Infected cheese weed mallow samples

Lane F: Non inoculative whitefly

Lane G: Sap mixture of healthy tobacco, tomato and cheese weed mallow plants.

\section{Development of Inoculative Whitefly Population}

The population trend of inoculative whiteflies was monitored throughout the year (January-December, 2011) in the studied areas. Whitefly samples were collected randomly from the top part of two hundred plant hosts scattered in one hectare of the tomato growing sites. The samples were collected using a cordless rechargeable vacuum cleaner adapted to collect insects into a plastic cylinder (vacuum sampling). The samples were transferred to laboratory within $2-3 \mathrm{~h}$ using icebox, identified and prepared for immuno-captured (IC)-PCR.

\section{IC-PCR Testing}

The IC-PCR was employed as described by Sawalha (2009a) using TYLCV-specific polyclonal IgG [20]. IC-PCR was used because of a close relationship between the capsid's retention in the whitefly vector and the virus's transmissibility as reported by Sawalha (2009b) [21]. The antibodies were cross-absorbed overnight with acetone-washed non-inoculative whiteflies. The reaction was employed using TYLCV-specific oligonucleotide primers as pointed above.

\section{Whitefly Migration from Plant Reservoirs to Tomato Fields}

An area of about 80 square meters of volunteer tobacco in Al-Zababdeih region, fully infested with whiteflies, was dusted with a day light fluorescent dust "Fire Orange," using a mechanical hand duster. Whitefly migration was recorded by positioning yellow sticky traps in tomato fields at various distances from the dusted plants. The traps were monitored daily for the appearance of fluorescent whiteflies [22].

In Al-Far'a region, a rectangular area of about 120 square meters of cheese weed mallow, 6 kilometers west of the main tomato production site was sprayed similarly with the fluorescent dust. The whitefly migration, from the infested area, toward the tomato fields was monitored daily as pointed above. The distance between the dusted areas of both districts was about $15 \mathrm{~km}$.

\section{Statistical Analysis}

Sample collection from the studied regions was done according to the standards of the Completely Randomized Design (CRD) where each reading was based on fifteen replicates from the same plant type. The Two-Sample Tests of Proportions (TSTP) was used to analyse of the data. The population difference of the inoculative whiteflies during the year was compared with the population at the starting points. The results were analyzed using a level of significance when $\dot{\alpha}=0.05$ [23].

\section{RESULTS \\ PCR Testing}

A subgenomic fragment of TYLCV with a fragment length of 2027 base pair (bp) was amplified by a combination of P1V (20-mer primer from the intergenic region) with 18-mer primer (P4C). The PCR was able to detect TYLCV from both inoculative whiteflies and infected plants by producing clear DNA bands when electrophoresed in agarose gel for 90 minutes (Fig, 2).

\section{Occurrence of TYLCV in Plant Reservoirs}

PCR tests showed that the virus was infecting cheese weed mallows throughout the year in Al-Far'a region. In addition, the virus infection of volunteer tomatoes started from May and increased to reach the maximum value during August. The maximum infections of both volunteer tomato and cheese weed mallow were $93 \%$ and $12 \%$ respectively (Fig. 3).

A different situation was recorded in both Al-Zababdeih and Qabatya where the infected volunteer tobaccos appeared throughout the year. The maximum rate of infections for such virus reservoirs in these regions were $7 \%$ and $6 \%$ in AlZababdeih and Qabatya respectively. In the case of cheese weed mallows of both regions, the first virus infection was recorded in March and increased to the maximum value of $12 \%$ in June. In both regions, the first record of virus infection of volunteer tomatoes was in May. The virus infection of those plants increased in October to the maximum rates of $75 \%$ and $74 \%$ in Qabatya and Al-Zababdeih respectively (Fig. 4 and 5).

\section{Development of Inoculative Whitefly Population}

The results showed that inoculative whiteflies in Al-Far'a region started to appear in March and increased rapidly until they reached the maximum population of $7 \%$ during July and August. Furthermore, the inoculative whiteflies in this region remained until the end of growing season in December. Statistical analysis revealed a significant difference of the in- 


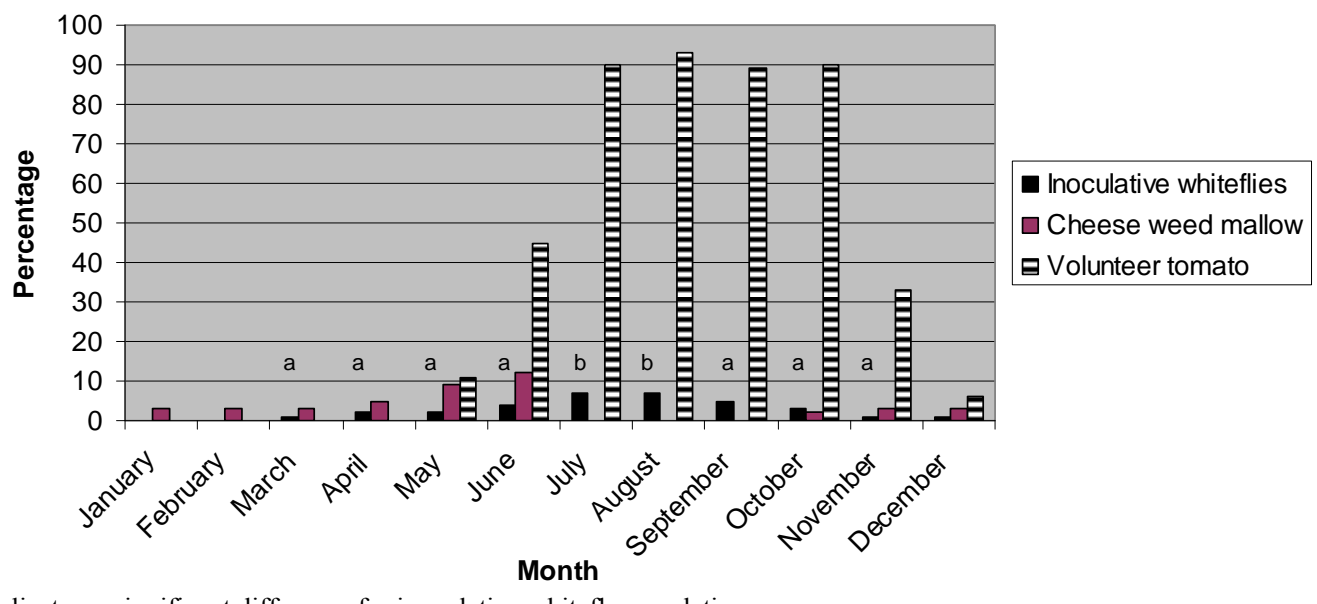

* Similar letters indicate no significant difference for inoculative whitefly population

Fig. (3). Population trend of TYLCV-inoculative whiteflies with regard to the virus reservoirs in tomato growing sites of Al-Far'a region.

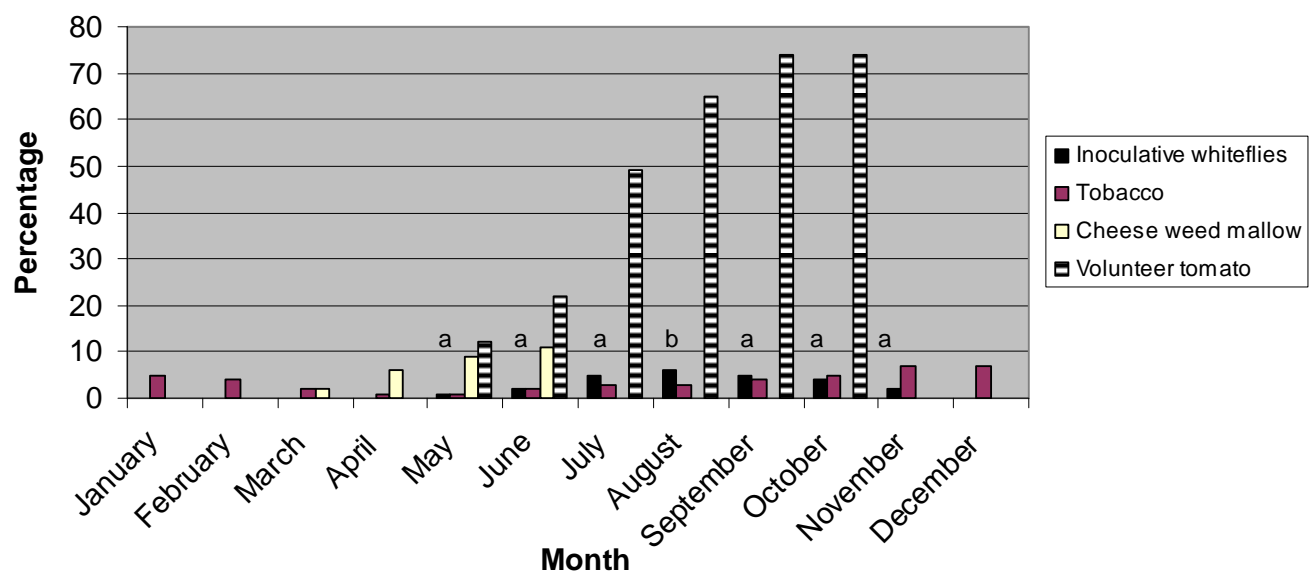

* Similar letters indicate no significant difference for inoculative whitefly population

Fig. (4). Population trend of TYLCV-inoculative whiteflies with regard to the virus reservoirs in tomato growing sites of Al-Zababdeih region.

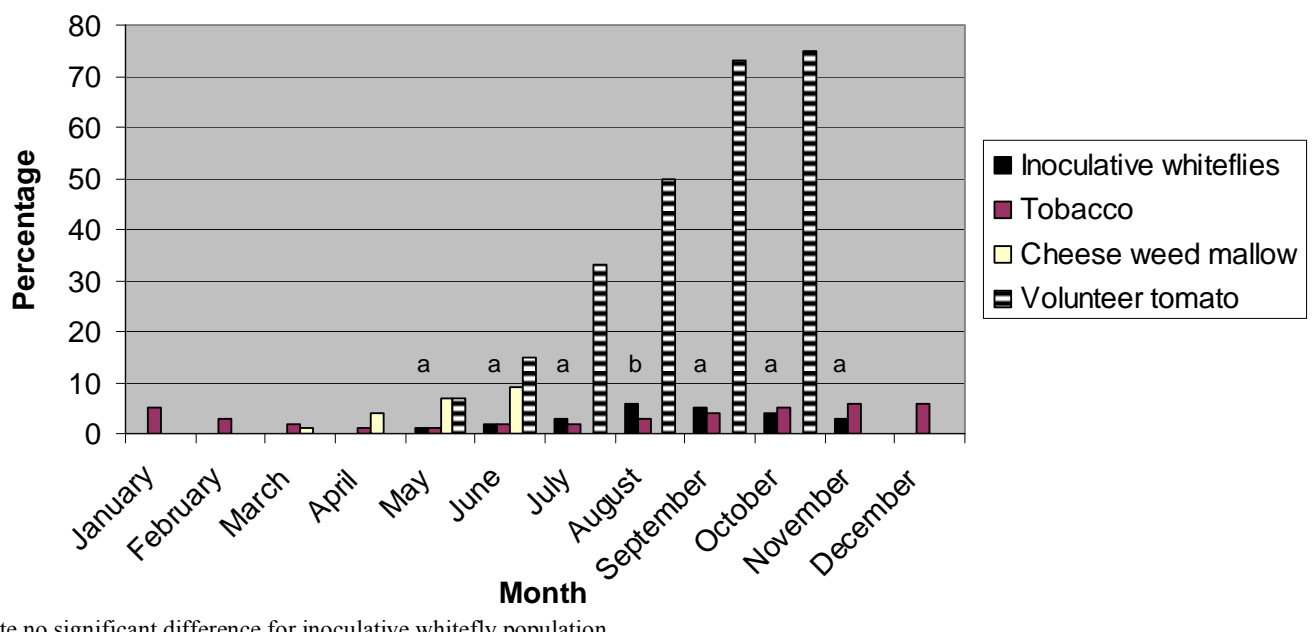

* Similar letters indicate no significant difference for inoculative whitefly population

Fig. (5). Population trend of TYLCV-inoculative whiteflies with regard to the virus reservoirs in tomato growing sites of Qabatya region.

oculative whiteflies population in July and August compared with the population at the starting point in March (Fig. 3).

In both Al-Zababdeih and Qabatya regions, the whiteflies started to appear in a low population during May then increased to reach the peak during August. The maximum whitefly population was $6 \%$ in both regions. Statistically, the significant difference of the whitefly population was re- corded only in August when compared with the population at the starting point in May.

A sudden spike of inoculative whitefly population was recorded after the first tomato transplantation during May in the studied regions. In addition, the population of inoculative whitefly started to decrease after October in both districts (Figs. 4 and 5). 


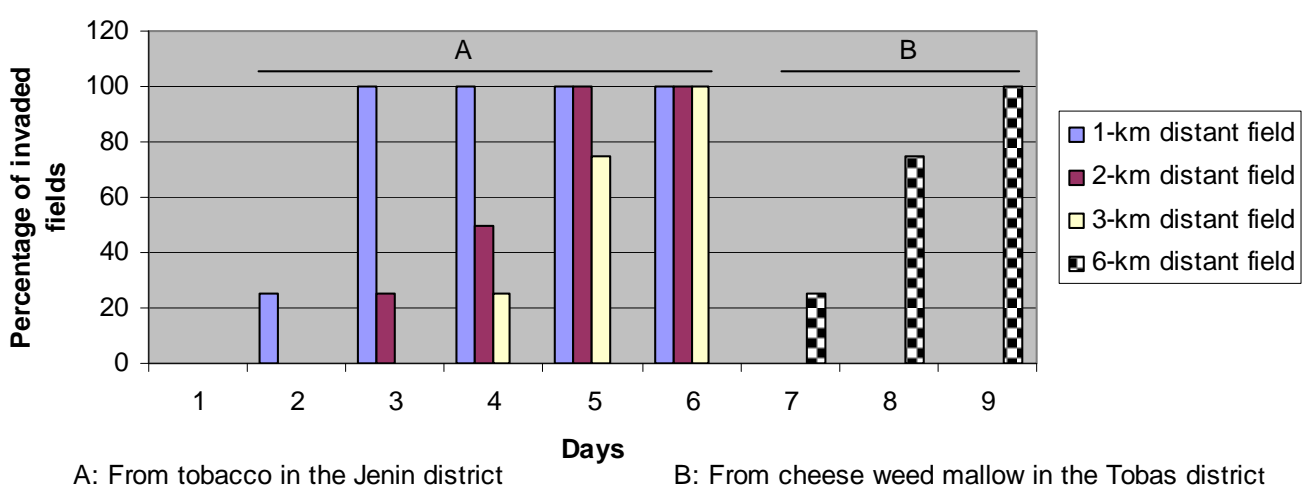

Fig (6). Rate of whitefly migration from virus reservoirs to tomato fields in the studied regions.

\section{Whitefly Migration from Plant Reservoirs to Tomato Fields}

The results showed that fluorescent whiteflies started to approach tomato fields, at a distance of $1-\mathrm{km}$ from the dusting site, two days after dusting in the Jenin district. In addition, the whiteflies needed three and four days to reach fields 2 - and $3-\mathrm{km}$ away from the dusted volunteer tobacco. In the Tobas district, the fluorescent whiteflies crossed a distance of 6-km and started to approach tomato fields one week after dusting. There was no record whatsoever of overlapping between the two dusted sites in the two districts that are 15 $\mathrm{km}$ apart and separated by huge mountains and populous urban areas (Fig. 6).

\section{DISCUSSION}

The current research highlights the essential role of inoculative whiteflies and virus plant reservoirs in the epidemiology of TYLCV in tomato growing sites. The population of those vectors is affected by the natural host plants which act as epicenters that enhance the virus outbreak in the region. The presence of virus reservoirs in the tomato growing sites especially volunteer tomato and tobacco plants may be attributed to poor agricultural practices, reckless behavior of traditional farmers, planting tobacco in tomato growing sites and extensive tomato cultivation. The suitable agricultural land in this region is very limited and farmers tend to use such available area extensively. As a result of that several crops especially tomato and tobacco are present in the same field or nearby fields. On the other hand, most farmers use traditional methods and practices as the majority of them are neither literate nor educated using experience passed down from their ancestors over the decades [24]. So, the competence of those reservoirs to maintain the virus and give a primary source of inoculum to newly established tomato crops is reasonable. Such a situation becomes more probable when those virus reservoirs are present in the same area with tomato crops. Although there is no definitive threshold number of those plant reservoirs, when their number becomes high enough they act as a potential source of the virus to tomato crops [4]. The infection of those crops may be enhanced by the favorable weather conditions of the region which activate the whitefly vectors for longer periods during the year [17]. Such conditions may also increase the possibility of virus transmission to natural host plants $([25,26]$. AlMusa (1986) reported that volunteer tomatoes growing near hedges surrounding citrus groves and along irrigation canals are reservoirs of TYLCV in the Jordan Valley [27].
Although volunteer tobacco plants have a lower rate of infection, their presence throughout the year enables them to be a potential primary virus source in the Jenin district. In this regard, Ioannou and Hadjinicolis (1991) isolated TYLCV from tobacco planted near tomato fields in Cyprus. Thus, the crop was considered a secondary host plant that could potentially act as a natural reservoir for TYLCV [28]. Al-Musa (1986) reported that tobacco serves as an important reservoir for TYLCV in the Jordan Valley [27]. On the other hand, cheese weed mallows were important virus reservoirs that play a significant role in the virus epidemiology in both districts. The plants survive and harbor the virus during the crop-free period of winter which enables them to be a primary virus source to newly established tomato fields. They start their active growth in the spring which is concomitant with the increase in the whitefly population and the tomatotransplanting period [7]. Although those tobaccos and cheese weed mallows were growing not far from the tomatogrowing areas, the whiteflies could move this distance and transmit the virus to tomato fields. In this regard, Cohen et al (1988) reported that whiteflies could transmit the TYLCV from Cynanchum acutum virus source, $7 \mathrm{~km}$ away from the tomato-growing sites in the Jordan Valley [22].

Despite the fact that low level of inoculative whiteflies was detected in tomato growing sites, they have a critical importance in the virus epidemiology. However, rough estimation showed that even if the percent of inoculative whiteflies is low during the population peak, 2,000-20,000 whiteflies land weekly on each square meter, thus ensuring high TYLCV infection within a short time (two months). A possible explanation for the relatively low percentage of viruliferous whiteflies within the field population may be due to the periodic acquisition phenomenon [29]. In this regard, Cohen et al. (1988) reported that only $5.4 \%$ of the whitefly population collected on C. acutum near tomato fields was inoculative in the Jordan Valley [22]. A low percent of inoculative whiteflies $(0.18-0.67 \%)$ was found also in the case of African cassava mosaic virus (ACMV) [30]. The jump in the population of inoculative whiteflies when farmers started their tomato growing seasons may be attributed to multiplication of the virus sources. In such a case, severe qualitative and quantitative yield reduction may reach $100 \%[4,31]$.

\section{CONCLUSION AND RECOMMENDATIONS}

Recognition of factors involved in the epidemiology of TYLCV may lead the way to efficient control of the disease by tackling the cycle at its weakest point. So, it is extremely 
important to be aware of the naturally infected hosts of TYLCV in order to be able to take control of and manage the virus. Ioannou (1987) observed a significant decrease in the disease incidence when the sources of inoculum were eliminated from tomato growing sites [32]. Therefore, the removal of volunteer tomato and tobacco plants, as well as cheese weed mallows from tomato growing sites is necessary to control the disease. In addition, controlling of those plants in March to May before the beginning of inoculative whitefly appearance may limit the spread of the virus in tomato fields. On the other hand, spraying pesticides to control the vector should be started with the time of tomato transplantation in the Tobas district while such a step can be delayed about one month after the crop transplantation in the Jenin district. Implementing the aforementioned procedures may provide a satisfactory level of disease control and prevention.

\section{CONFLICT OF INTEREST}

None declared.

\section{ACKNOWLEDGEMENT}

I would like to thank Dr. Feras Sawalha, An-Najah National University, for the linguistic editing of this article.

\section{REFERENCES}

[1] Palestinian Central Bureau of Statistics. Agricultural statistics, Ramallah- Palestine, 2008; pp. 77-100.

[2] Willcox J, Catignani G, Lazarus S. Tomatoes and cardiovascular health. Crit Rev Food Sci Nutr 2003; 43: 1-18.

[3] Ali-Shtayeh M, Jamous R. Traditional Arabic Palestinian herbal medicine, TAPHM, Biodiversity and Environmental Research Center (BERC), Til, Nablus, Palestine 2008; pp. 49-50.

[4] Pico B, Diez M, Muez, F. Viral disease causing the greatest economic losses to the tomato crop. II. The tomato yellow leaf curl virus- A review. Scientia Horticult 1996; 67: 151-96.

[5] Moriones F, Navas-Castillo J. Tomato yellow leaf curl virus, an emerging virus complex causing epidemics worldwide. Virus Res 2000; 71: 123-34.

[5] Czosnek H, Ghanim M, Morin S, Rubinstein G, Friedman V, Zeidan M. Whiteflies: vectors, and victims (?), of geminiviruses. Adv. Virus Res 2001; 57: 291-322.

[7] Sawalha H. Whitefly population and incidence of tomato yellow leaf curl virus in tomato fields grown in the northern regions of the West Bank. Al-Aqsa Uni J (Nat Sci Ser) 2010; 13: 7-24.

[8] Oetting R, Yunis H. Field guide to common insects, mites, and diseases of greenhouse grown sweet peppers, and tomatoes. Kfar Qari: Hakohav Press 2004; p. 69.

[9] Mansour A, Al-Musa A. Tomato yellow leaf curl virus: host range and virus relationships. Plant Pathol 1992; 41: 122-5.

[10] Kashina B, Mabagala R, Mpunami A. Biomolecular relationships among isolates of tomato yellow leaf curl tanzania virus. Phytoparasitica 2003; 31: 188-99.

[11] Czosnek H, Ber R, Antignus Y, Cohen S, Navot N, Zamir D. Isolation of tomato yellow leaf curl virus, a geminivirus. Phytopathology 1988; 78: 508-12.

[12] Fauquet C, Bisaro D, Briddon R, et al. Revision of taxonomic criteria for species demarcation in the family geminiviridae, and an updated list of begomovirus species. Arch Virol 2003; 148: 405-21.
[13] Brown J, Czosnek H. Whitefly transmission of plant viruses. In RT Plumb, Ed, Advance of Botanical Research. New York: Academic Press 2000; vol. 36: pp. 65-100.

[14] Polston J, Sherwood T. Pymetrozine interferes with transmission of tomato yellow leaf curl virus by the whitefly Bemisia tabaci. Phytoparasitica 2003; 31: 490-8.

[15] Byrne D, Bellows T. Whitefly biology. Ann Rev Entomol 1991; 36: 431-57.

[16] Sawalha H. Occurrence and prevalence of four viruses infecting tomatoes in northern districts of West Bank, Palestinian territories. BioTechnol Indian J 2011; (In Press).

[17] Palestinian Central Bureau of Statistics. Meteorological conditions in the Palestinian territories annual report, Ramallah- Palestine 2011; pp. 1-63.

[18] Khasdan V, Levin I, Rosner A, et al. DNA markers for identifying hiotypes B and Q of Bemisia tabaci (Hemiptera: Aleyrodidae) and studying population dynamics. Bull Entomol Res 2005; 95: 605-13.

[19] Navot N, Zeidan M, Pichersky E, Zamir D, Czosnek H. Use of the polymerase chain reaction to amplify tomato yellow leaf curl virus DNA from infected plants and viruliferous whiteflies. Phytopathology 1992; 82: 1199-202.

[20] Sawalha H. The use of PCR, IC-PCR, TAS-ELISA, TBIA, and biological methods to determine the time needed to detect TYLCV in inoculated jimsonweeds. The First Conference on Biotechnology Research and Application in Palestine, Furno Hall, April 3-4, Bethlehem University, Bethlehem, Palestine, 2009.

[21] Sawalha H. Palestinian isolate of tomato yellow leaf curl virus: capsid and nucleic acid retention in Bemisia tabaci, transmission, and field study of virus association with the vector and non-vector insects. An - Najah Univ J Res (N. Sc.) 2009b; 23: 93-115.

[22] Cohen S, Kern J, Harpaz I, Ben Joseph R. Epidemiological studies of the tomato yellow leaf curl virus (TYLCV) in the Jordan Valley, Israel. Phytoparasitica 1988; 16: 259-70.

[23] Lind D, Marchal W, Wathen S. Statistical techniques in business and economics, $12^{\text {th }}$ ed. New York, McGraw-Hill Irwin 2005; pp. 262-63.

[24] Sawalha H. Misuse of pesticides by vegetable farmers in Palestinian territories and recommendations for their proper use. IUG J Nat Eng Stud 2012; 20: 41-54.

[25] Jetter K, Alston J, Farquharson R. Private investment in exotic pest control technology, the case of silver leaf whitefly in California, University of California Agricultural Issues Center, 2001; pp. 1-60.

[26] Gerling D. Whiteflies: their bionomics, pest status and management. UK: Intercept Ltd 1990; pp. 57-112.

[27] Al-Musa A. Tomato yellow leaf curl virus in Jordan: epidemiology and control. Dirasat 1986; XII: 199-208.

[28] Ioannou N, Hadjinicolis A. Epidemiology and control of tomato yellow leaf curl virus in Cyprus, Institute National Dela Recherche Agronomoqua, Montfuvet (France), Center d' Aignon, Amelioratio des Plantes Marai Chers, Resistance of tomato to TYLCV (tomato yellow leaf curl virus), Montfaret (France) INRA 1991; pp. 3-6.

[29] Cohen S, Lapidot M. Appearance and expansion of TYLCV, a historical point of view, Department of Vegetable Research, Institute of Plant Sciences, Volcani Center, ARO, Bet Dagan, Israel, 2007; pp. 3-12.

[30] Colvin J, Fishpool L, Fargette D, Sherigton J, Fauquet C. Bemisia tabaci (Hemiptera: Aleyrodidae) trap catches in a cassava field in Côte d'Ivoire in relation to environmental factors and the distribution of African cassava mosaic disease. Bull Entomol Res 1998; 88: pp. 369-78.

[31] Nakhla M, Maxwell D, Martinez R, Carvalho M, Gilbertson R. Widespread occurrence of the eastern mediterranean strain of tomato yellow leaf curl geminivirus in tomatoes in the Dominican Republic. Plant Dis 1994; 78: 926.

[32] Ioannou N. Cultural management of tomato yellow leaf curl disease in Cyprus. Plant Pathol 1987; 36: 367-73. 